Jurnal Pendidikan Dasar, 6 (2), Desember 2018

\title{
PENGARUH MODEL PEMBELAJARAN KOOPERATIF TIPE COOPERATIVE INTEGRATED READING AND COMPOSITION (CIRC) TERHADAP HASIL BELAJAR ILMU PENGETAHUAN SOSIAL SISWA KELAS V SD NEGERI 3 ELLA HULU
}

\author{
Fatimah $^{1}$, Ahmad Khoiri' ${ }^{2}$, Syaiful Rakhman ${ }^{3}$ \\ ${ }^{1}$ Mahasiswa Lulusan Program Studi PGSD Tahun 2018 \\ ${ }^{2 \cdot 3}$ Dosen STKIP Melawi \\ Jl. RSUD Melawi km. 04 Kec. Nanga Pinoh Kab. Melawi Kalimantan Barat \\ fatimah25012014@gmail.com, Khoiri007@yahoo.com, \\ syaifulrakhman24@yahoo.com
}

\begin{abstract}
This study aims to determine the effect of cooperative learning model type Cooperative Integrated Reading and Composition (CIRC) on learning outcomes of Social Sciences class V students of public elementary school 3 Ella Hulu before and after applying cooperative learning model type Cooperative Integrated Reading and Composition (CIRC). This research was conducted in class V at Ella Hulu 3 Public Elementary School. The type of research was Pre-experimental with the One Group Pretest and Postest design. Validation used was content validation and construct. The sample technique used is saturated sample, which is that all members of the population of 17 people were sampled. Date collection techniques use tests in the formof written tests. To analyze date using the t-test. The results of the research at the first meeting before applying the cooperative learning model type Cooperative Integrated Reading and Composition (CIRC) obtained a value of 770 with an average value of 45.29 . While the results of the study after applying the model applying cooperative learning model type Cooperative Integrated Reading and Composition (CIRC) obtain a value of 1280 with an average value of 75.29. Based on the results of the study it can be concluded that there is a significant effect of applying the cooperative learning model of Cooperative Integrated Reading and Composition (CIRC) type on the social science learning outcomes of the fifth grade students of Ella Hulu State Elementary School, namely $\mathrm{t}$ count $>\mathrm{t}$ table $(5,400>2,042)$.
\end{abstract}

Keywords: Cooperative Learning Model Type Cooperative Integrated Reading and Composition (CIRC), Learning Outcomes

Abstrak: Penelitian ini bertujuan untuk mengetahui pengaruh model pembelajaran kooperatif tipe Cooperative Integrated Reading and Composition (CIRC) terhadap hasil belajar Ilmu pengetahuan Sosial siswa kelas V SD Negeri 3 Ella Hulu sebelum dan sesudah menerapkan model pembelajaran kooperatif tipe Cooperative Integrated Reading and Composition (CIRC).Penelitian ini dilaksanakan pada kelas V di SD Negeri 3 Ella Hulu. Metode penelitian yang digunakan adalah penelitian kuantitatif dengan menggunakan deskriptif kuantitatif. Jenis penelitian

74| J P D, p-I S S N : $2252-8156$, e - I S S N : $2579-3993$ 
adalah Pre-eksperimental dengan desain One Group Pretest and Postest. Validasi yang digunakan adalah validasi isi dan konstruk. Teknik sampel yang digunakan adalah teknik sampel jenuh yaitu semua anggota populasi yang berjumlah 17 orang dijadikan sampel. Teknikpengumpulan data menggunakantesdalambentuktestertulis. Untuk menganalisis data menggunakan uji-t. Hasil penelitian pada pertemuan pertama sebelum menerapkan model pembelajaran kooperatif tipe Cooperative Integrated Reading and Composition (CIRC) memperoleh nilai sebesar 770 dengan nilai rata-rata 45,29 . Sedangkan hasil penelitian setelah menerapkan model menerapkan model pembelajaran kooperatif tipe Cooperative Integrated Reading and Composition (CIRC) memperoleh nilai sebesar 1280 dengan nilai rata-rata 75,29. Berdasarkan hasil penelitian dapat di simpulkan bahwa terdapat pengaruh yang signifikan menerapkan model pembelajaran kooperatif tipe Cooperative Integrated Reading and Composition (CIRC) terhadap hasil belajar ilmu pengetahuan sosial siwa kelas V SD Negeri 3 Ella Hulu yaitu $t_{\text {hitung }}>t_{\text {tabel }}(5,400>2,042)$.

Kata Kunci: Model Pembelajaran Kooperatif Tipe Cooperative Integrated Reading and Composition (CIRC), Hasil Belajar

$\mathrm{I}$

lmu pengetahuan sosial adalah bahan

kajian yang terpadu yang merupakan penyederhanaan,adaptasi,seleksi,dan

modifikasi yang diorganisasikan dari konsep-konsep dan keterampilanketerampilan sejarah, geografi, sosiologi, antropologi, dan ekonomi. Studi yang memperhatikan bagaimana orang membangun kehidupan yang lebih baik bagi dirinya dan anggota keluarganya, bagaimana memecahkan masalah, bagaimana orang hidup bersama, bagaimana orang mengubah dan diubah oleh lingkungannya.

Tujuan pendidikan ilmu pengetahuan sosial ditujukan untuk mengembangkan pengetahuan dan keterampilan dasar siswa yang berguna untuk kehidupan sehari-harinya. Ilmu pengetahuan sosial sangat erat kaitannya dengan persiapan anak didik untuk berperan aktif atau berpartisipasi dalam pembangunan Indonesia dan terlibat dalam pergaulan masyarakat dunia (global society). Ilmu pengetahuan sosial harus dilihat sebagai suatu komponen penting dari keseluruhan pendidikan kepada anak. Ilmu pengetahuan sosial memerankan peranan yang signifikan dalam mengarahkan dan membimbing anak didik pada nilai-nilai dan perilaku yang demokratis, memahami dirinya dalam konteks kehidupan masa kini, memahami tanggung jawabnya sebagai bagian dari masyarakat global yang interdependen.

Namun, selama ini mata pelajaran ilmu pengetahuan sosial selalu dianggap

75| J P D, p-I S S N : $2252-8156$, e - I S S N : 2579 - 3993 
sebelah mata oleh sebagian orang, dan banyak yang mengatakan bahwa ilmu pengetahuan sosial merupakan pelajaran yang membosankan dan kurang menantang karena kebanyakan materinya hanya berupa hapalan, dan hal ini merupakan masalah bagi mata pelajaran ilmu pengetahuan sosial itu sendiri. masalah ini semakin serius manakala dihadapkan pada kenyataan bahwa, selama ini mata pelajaran ilmu pengetahuan sosial kurang mendapatkan perhatian yang semestinya. Padahal sebenarnya mata pelajaran ilmu pengetahuan sosial merupakan pelajaran yang sangat penting karena dengan belajar ilmu pengetahuan sosial dapat membimbing siswa beradaptasi dalam lingkungan sosialnya, dan dapat membantu siswa dalam menghadapi masalah-masalah sosial yang terjadi di masyarakat dengan lebih bijaksana. langkah pertama yang harus ditempuh untuk menuju ke arah pembaharuan sistem pembelajaran ilmu pengetahuan sosial di sekolah adalah perbaikan kualitas (mutu) tenaga pendidiknya. Mereka perlu dibekali tentang pola pembelajaran ilmu pengetahuan sosial terpadu dengan mantap, dan dilatih dengan model-model pembelajaran berpusat pada peserta didik, sehingga pembelajaran akan lebih bermakna. penerapan terpadu dalam pembelajaran ilmu pengetahuan sosial mengandung arti yang strategis untuk pembangunan nasional atau kehidupan berbangsa dan bernegara.

Berhasil tidaknya tujuan kegiatan proses belajar mengajar di sekolah banyak tergantung pada bagaimana strategi guru mengelola proses pembelajaran di dalam kelas. Rusman (2014: 58) mengungkapkan "guru merupakan factor penentu yang sangat dominan dalam pendidikan pada umumnya, karena guru memegang peranan dalam proses pembelajaran, Dimana proses pembelajaran merupakan inti dari proses pendidikan secara keseluruhan". Menurut syambasril dan umar (2013: 10) guru memegang peran sentral dalam proses pembelajaran, setidak-tidaknya menjalankan tiga macam tugas utama, yaitu: merencanakan, melaksanakan, dan evaluasi atau penilaian. jadi guru merupakan salah satu faktor yang memegang peranan dalam proses pembelajaran yang setidak-tidaknya menjalankan tiga macam tugas utama, yaitu merencanakan, melaksanakan, dan evaluasi atau penilaian. Salah satu indikator keberhasilan suatu pendidikan dapat di lihat dari hasil belajar siswa. 
Hasil belajar siswa adalah kemampuan yang di peroleh anak setelah melalui kegiatan belajar. Karena belajar itu sendiri merupakan suatu bentuk perubahan perilaku yang relatif menetap. Dalam kegiatan pembelajaran atau instruksional, biasanya guru menetapkan tujuan belajar. Anak yang berhasil dalam belajar adalah yang berhasil mencapai tujuan-tujuan pembelajaran atau instruksional. Untuk mengetahui apakah hasil belajar yang dicapai telah sesuai dengan tujuan yang di kehendaki dapat diketahui melalui evaluasi.

Sunal (1993: 94), menyatakan bahwa evaluasi merupakan proses penggunaan informasi untuk membuat pertimbangan seberapa efektif satu program telah memenuhi kebutuhan siswa. Selain itu, dilakukan evaluasi atau penilaian dapat dijadikan feedback atau tindaklanjut, atau bahkan cara mengukur tingkat penguasan siswa. Prestasi belajar siswa tidak saja diukur dari tingkat penguasan ilmu pengetahuan, tetapi juga dari sikap dan keterampilan Dengan demikian penilaian hasil belajar siswa mencakup segala hal yang di pelajari di sekolah baik itu menyangkut pengetahuan, sikap, dan keterampilan yang berkaitan dengan mata pelajaran diberikan kepada siswa.
Berdasarkan hasil pengamatan peneliti selama melaksanakan Praktik Pengalaman Lapangan (PPL) di SD Negeri 3 Ella Hulu selama 3 bulan yang di mulai dari tanggal 23 Agustus sampai dengan 23 November 2017. Peneliti menemukan masalah dalam proses pembelajaran khususnya di kelas V pada mata pelajaran Ilmu Pengetahuan Sosial, hal ini terlihat dari guru yang mengajar dalam menyampaikan materi belum sepenuhnya di sertai dengan penggunaan media atau alat peraga seperti peta, globe, atlas, dan gambar yang menunjang proses pembelajaran ilmu pengetahuan sosial, sehingga pemahaman siswa menjadi relatif kurang maksimal, dengan demikian diperlukan pengulangan-pengulangan kembali mengenai materi yang telah diajarkan, bahkan saat proses pelajaran berlangsung siswa ada yang bermain. Selain itu, siswa merasa bosan dengan metode atau model yang kurang bervariasi dalam proses pembelajaran sehingga siswa kurang aktif dan kurang memahami materi pembelajaran. Permasalahan tersebut, mengakibatkan hasil belajar yang didapatkan siswa kelas V SD Negeri 3 Ella Hulu yang berjumlah 17 Orang siswa dengan nilai rata-rata 46,76 sedangkan Kriteria Ketuntasan Minimal (KKM) yang di 
tetapkan di sekolah ini yaitu 65 . Hal ini terlihat dari 1 orang siswa mendapatkan nilai 25,1 orang siswa mendapat nilai 30, dan 3 orang siswa mendapat nilai 35 . 1 orang siswa mendapat nilai 40,3 orang siswa mendapat nilai 45,3 orang siswa mendapat nilai 50 , dan 1 orang siswa mendapat nilai 55. 2 orang siswa mendapat nilai 60,1 orang siswa mendapat nilai 65 , dan 1 siswa orang mendapat nilai 70 .

Melihat permasalahan yang ada peneliti tertarik untuk menggunakan model pembelajaran kooperatif tipe Cooperative Integrated Reading and Composition (CIRC).Dimana model pembelajaran kooperatif tipe Cooperative Integrated Reading and Compesition (CIRC) melibatkan setiap siswa aktif dalam proses pembelajaran, melatih siswa untuk berani mengemukan pendapat atau sanggahan secara lisan dan tertulis, mempermudah siswa memahami materi pelajaran, serta meningkatkan kemampuan siswa dalam menulis suatu peristiwa.

Berdasarkan masalah yang terjadi, peneliti menawarkan model pembelajaran kooperatif tipe Cooperative Integrated Reading and Composition (CIRC) untuk mengatasi masalah tersebut dengan memberikan pengaruh hasil belajar siswa pada mata pelajaran ilmu pengetahuan sosial setelah menerapkan model pembelajaran kooperatif tipe Cooperative Integrated Reading and Composition (CIRC) pada satu kelas yakni kelas V SD Negeri 3 Ella Hulu.

Peneliti semakin yakin bahwa dengan menerapkan model pembelajaran kooperatif tipe Cooperative Integrated Reading and Composition (CIRC) dapat memperbaiki hasil belajar siswa, karena adanya penelitian terdahulu yang di lakukan oleh Putu Agus Kuswandana (2014) Hasil penelitian menunjukan bahwa terdapat perbedaan dengan menggunakan model pembelajaran kooperatif tipe CIRC dan kelompok siswa yang belajar menggunakan model konvensional pada mata pelajaran IPS siswa kelas $\mathrm{V}$ pada semester 1 tahun pelajaran 2013/2014 SD di Desa Penarukan. Hal ini di tunjukanoleh $t_{\text {hit }} \quad 11,84>t_{\text {tabel }} 2,021$. Skor yang di peroleh antara siswa yang belajar menggunakan model pembelajaran CIRC yaitu 17,42 yang berada di kategori tinggi dan siswa yang belajar menggunakan model konvensional yaitu 13,91 yang berada di kategori sedang.

Penelitan yang dilakukan oleh Ratna (2013), menunjukan bahwa terdapat terdapat perbedaan yang 78| J P D, p-IS S N : $2252-8156$, e - I S S N : $2579-3993$ 
signifikan hasil belajar IPS antara siswa yang dibelajarkan dengan model pembelajaran CIRC dan siswa yang dibelajarkan dengan model pembelajaran konvensional. Dari ratarata $(X)$ hitung, diketahui $X$ kelompok eksperimen $=21,78$ dan $X$ kelompokkontrol $=11,92$. Hal ini berarti bahwa Xeksperimen $>$ Xkontrol, sehinggadapat di simpulkan bahwa pembelajaran dengan model pembelajaran CIRC berpengaruh terhadap hasil belajar. Dari penjelasan diatas,penelitimelaksanakan penelitian Pre-Eksperimentaluntuk membuktikan bahwa melalui penerapan model pembelajaran kooperatif tipe Cooperative Integrated Reading and Composition (CIRC) pada mata pelajaran Ilmu Pengetahuan Sosial dapat berpengaruh terhadap hasil belajar siswa di kelas V SD Negeri 3 Ella Hulu..

\section{METODELOGI PENELITIAN}

Metode yang peneliti gunakan dalam penelitian adalah metode penelitian kuantitatif. Jenis penelitian yang digunakan adalah Pra Exsperimental dengan designs one group pretest posttest untuk mengetahui pengaruh model pembelajaran kooperatif tipe Cooperative Integrated Reading And Composition (CIRC) terhadap hasil belajar ilmu pengetahuan sosial siswa, populasi dalam penelitian ini adalah siswa kelas V SD Negeri 3 Ella Huludengan jumlah siswa 17 orang. Dalam penarikan sampel, peneliti menggunakan teknik nonprobality yaitu sampel jenuh atau yang sering disebut total sampling. Sampel dalam penelitian ini adalah siswa kelas V SD Negeri 3 Ella Hulu yang berjumlah 17 orang siswa, dengan rincian 15 orang siswa laki-laki dan 2 orang siswi perempuan.

Penelitian ini dilaksanakan di kelas SD Negeri 3 Ella Hulu, Kecamatan Menukung, Kabupaten Melawi, Provinsi Kalimantan Barat. Penelitian ini dilaksanakan pada tanggal 7 Mei sampai dengan 19 Mei 2018 pada semester genap tahun ajaran 2018/2019. Penelitian dilaksanakan selama 4 kali pertemuan yaitu pertemuan pertama pada hari Senin tanggal 7 Mei, peneliti mengadakan pretest (tes awal), sedangkan pada tanggal 9 Mei dan tanggal 14 Mei peneliti menerapkan model pembelajaran kooperatif tipe Cooperative Integrated Reading And Composition (CIRC) dan pada tanggal 16 Mei peneliti mengadakan postest (test akhir). Dalam penelitian ini terdapat Variabel bebas dan variabel terikat. Variabel bebas merupakan variabel yang mempengaruhi atau yang menjadi sebab perubahannya atau timbulnya variabel 
dependen. Variabel bebas dalam (CIRC), kemudian peneliti memberikan penelitian ini adalah model tes akhir atau postest kepada siswa pembelajaran kooperatif tipe setelah menerapkan model pembelajaran Cooperative Integrated Reading And kooperatif tipe Cooperative Integrated Composition (CIRC). Sedangkan Readingand Composition (CIRC) dan variabel terikat adalah variabel yang materi keragaman suku bangsa dan dipengaruhi atau yang mnjadi akibat budaya di Indonesia telah tuntas karena adanya variabel bebas. Variabel dibahas. Instrumen yang digunakan terikat dalam penelitian ini adalah hasil belajar ilmu pengetahuan sosial siswa kelas V SD Negeri 3 Ella Hulu.

Penelitian ini menggunakan dua metode dalam pengumpulan data, yaitu teknik tes dan teknik dokumentasi. Instrumen tes digunakan untuk mendapatkan data mengenai hasil belajar siswa, sedangkan dokumentasi digunakan sebagai pembuktian bahwa benar-benar diadakan penelitian di sekolah SD Negeri 3 Ella Hulu. Data tes digunakan untuk mengetahui hasil belajar siswa. Tes ditujukan kepada siswa yang menjadi sampel dalam penelitian ini untuk melihat pengaruh sebelum dan sesudah menerapkan model pembelajaran kooperatif tipe Cooperative Integrated Reading and Composition (CIRC). Peneliti memberi tes awal atau pretest kepada siswa untuk mengetahui kemampuan awal sebelum menerapkankan model pembelajaran kooperatif tipe Cooperative IntegratedReading and Composition sedangkan skor terendah 20. Sedangkan 80 | J P D, p - I S S N : 2252 - 8156 , e - I S S N : 2579 - 3993 
nilai postest di peroleh jumlah skor keseluruhan adalah 1280 dengan ratarata 75,29, skor tertinggi 100 dan skor terendah 50. hasil uji t data pretest dan posttest pada kelas V SD Negeri 3 Ella Hulu di peroleh $t_{\text {hitung }}$ sebesar 5,400 dan $t_{\text {tabel }}$ sebesar 2,042, karena $t_{\text {hitung }} 5,400$ $>t_{\text {tabel }} \quad 2,042$ maka $H_{a}$ diterima.Jadi, dapat disimpulkan bahwa terdapat pengaruh yang signifikan menerapkan model kooperatif tipe Cooperative Integrated Reading and Composition (CIRC) terhadap hasil belajar siswa, ternyata lebih baik dibandingkan dengan belum diterapkan model kooperatif tipe Cooperative Integrated Reading and Composition (CIRC). Dengan perbedaan tersebut bahwa model kooperatif tipe Cooperative Integrated Reading and Composition (CIRC) bisa digunakan sebagai salah satu untuk meningkatkan hasil belajar siswa khususnya pada mata pelajaran ilmu pengetahuan sosial.

Model pembelajaran kooperatif tipe Cooperative Integrated Reading And Composition (CIRC) merupakan pembelajaran menyeluruh dengan cara membaca dan menulis yang melibatkan kerja sama murid dalam suatu kelompok dimana kesuksesan kelompok tergantung pada kesuksesan masingmasing individu dalam kelompok tersebut. Hal ini terlihat pada langkah- langkah penerapan model pembelajaran kooperatif Tipe Cooperative Integrated Reading And Composition (CIRC).

Penelitian dilakukan pada siswa kelas V SD Negeri 3 Ella Hulu dengan jumlah siswa 17 orang yang diberikan perlakuan atau treatmen menggunakan model pembelajaran kooperatif tipe Cooperative Integrated Reading And Composition (CIRC) pada mata pelajaran ilmu pengetahuan sosial dengan materi keragaman suku bangsa dan budaya di Indonesia. Pada pertemuan pertama siswa diberikan soal pretest untuk mengetahui kemampuan awal siswa sebelum penerapan model pembelajaran kooperatif tipe Cooperative Integrated Reading And Composition (CIRC). Setelah melakukan pretest selanjutnya pada pertemuan kedua dan ketiga peneliti melakukan penerapan model pembelajaran kooperatif tipe Cooperative Integrated Reading And Composition (CIRC) pada materi Keragaman Suku Bangsa dan Budaya di Indonesia. Saat pertemuan pertama menerapakan model pembelajaran kooperatif tipe Cooperative Integrated Reading And Composition (CIRC) mengalami beberapa kendala yaitu siswa masih bingung dengan model pembelajaran yang diterapkan. pada 
pertemuan kedua menerapkan model pembelajaran kooperatif tipe Cooperative Integrated Reading And Composition (CIRC) siswa sudah mulai mengerti dengan model pembelajaran yang diterapkan. Setelah menerapkan model pembelajran kooperatif tipe Cooperative Inegrated Reading And Composition (CIRC), selanjutnya pada pertemuan keempat siswa diberikan soal postest untuk mengetahui pengaruh penerapan model pembelajaran kooperatif tipe Cooperative Integrated Reading And Composition (CIRC) terhadap hasil belajar siswa.

Berdasarkan hasil analisis diatas menjelaskan bahwa sebelum menerapkan model pembelajaran Cooperative Integrated Reading and Composition (CIRC) (Pretest) pada penelitian ini memperoleh skor dengan angka terendah yaitu 20 dan angka tertinggi yaitu 70 kemudian menerapkan model pembelajaran Cooperative Integrated Reading And Composition (CIRC)(Posttest) pada pada penelitian ini memperoleh angka terendah 50 dan angka tertinggi 100. Kemudian setelah dilakukan analisis rata-rata hasil pretest diketahui bahwa rata-rata pretest adalah 45,29 dan rata-rata posttestadalah 75,29 berarti hal ini menunjukkan bahwa ada perbedaan selisih rata-rata yang signifikan antara sebelum dan sesudah diberi perlakuan yaitu 30 .

Berdasarkan dari hasil uji hipotesis maka diketahui bahwa $t_{\text {tabel dalam }}$ penelitian ini adalah 2,042, Oleh karena itu, kita dapat mengetahui $t_{\text {hitung }}>$ $t_{\text {tabel }}$ dengan angka 5,400>2,042. Oleh sebab itu, maka $\mathrm{H}_{0}$ ditolak dan $\mathrm{H}_{\mathrm{a}}$ diterima, bahwa dalam penelitian ini adaperbedaan rata-rata yang signifikan sebelum dan sesudah diberikan perlakuan.

Kesimpulannya terdapat pengaruh yang signifikan terhadap hasil belajar siswa dengan menggunakan model pembelajaran Cooperative Integrated Reading and Composition (CIRC)pada siswa kelas V SD Negeri 3 Ella Hulu. Penelitian ini sama dengan penelitian yang dilakukan oleh Putu Agus Kuswandana dan Ratna yaitu $t_{\text {hitung }}>$ $\mathrm{t}_{\text {tabelmaka terdapat perbedaan }}$ hasilbelajar setelah diterapkannya model pembelajaran Cooperative Integrated Reading and Composition (CIRC).

\section{SIMPULAN}

Hasil penelitian pada siswa kelas V SD Negeri 3 Ella Hulu, Kecamatan Menukung, Kabupaten Melawi, Provinsi Kalimantan Barat maka dapat disimpulkan bahwa hasil belajar siswa sebelum menerapkan model pembelajaran kooperatif tipe 
Cooperative Integrated Reading and Composition (CIRC) pada mata pelajaran Ilmu Pengetahuan Sosial siwa memperoleh nilai sebesar 770, dengan nilai rata-rata 45,2. Hasil belajar siswa sesudah menerapkan model pembelajaran kooperatif tipe Cooperative Integrated Reading and Composition (CIRC) memperoleh jumlah nilai sebesar 1280, dengan nilai rata-rata 75,2 . Terdapat pengaruh yang signifikan dengan menerapakan model pembelajaran kooperatif tipe Cooperative Integrated Reading and Composition (CIRC) terhadap hasil belajar ilmu pengetahuan sosial siwa kelas V SD Negeri 3 Ella Hulu yaitu $t_{\text {hitung }}>t_{\text {tabel }}(5,400>2,042)$.

\section{DAFTAR PUSTAKA}

Afandi, M., Chamalah, E dan Wardani, O. P. 2013. Model dan Pembelajaran di Sekolah. Semarang: Unissula Press.

Anggoro, M. T. 2008. Metode Penelitian. Jakarta: Universitas Terbuka

Arikunto, S. 2010. Prosedur Penelitian. Jakarta: Rineka Cipta.

Huda, M. 2013. Model-Model Pengajaran dan Pembelajaran. Yogyakata. Pustaka Pelajar.

Kuswandan, P. A. 2014. Pengaruh Model Pembelajaran Kooperatif
Tipe CIRC Terhadap Hasil Belajar IPS Siswa Kelas V Di Desa Penarukan. (online). Portalgarud.org/article.php?article $=145707 \& \mathrm{val}=1342 \quad$ (diakses 20 Desember 2017)

Ratna. 2013. Pengaruh Model Pembelajaran Cooperative Integrated Reading And Composition (CIRC) Terhadap Hasil Belajar IPS Kelas IV Gugus I Kecamatan Manggis. (Online).https://ejournal.

Undiksha. ac.id / indek. php/JJPGSD/article/view/699.

(diakses 20 Desember 2017)

Sugiyono. 2015. Metode Penelitian Pendidikan Pendekatan Kuantitatif, Kualitatif, dan $R \& D$. Bandung :Alpabeta.

Sugiyono. 2017. Metode Penelitian Kuantitatif, Kualitatif, dan $R \& D$. Bandung : Alpabeta.

Suprijono. 2011. Cooperative Learning (Teori dan Aplikasi PAIKEM). Yogyakarta: Pustaka Pelajar Surapranata, S. 2009. Analisis, Validitas, Reliabelitas, dan Interprestasi Hasil Tes Implementasi Kurikulum 2004. Bandung

Susanto. 2013. Teori Belajar dan Pembelajaran di Sekolah Dasar. Jakarta: Kencana Prenada Media Group. 
Jurnal Pendidikan Dasar, 6 (2), Desember 2018

Uno, H. B. 2009. Belajar Dengan

Pendekatan Paikem. Jakarta : Raja

Grafindo Persada.

Usman, H. 2012. Pengantar Statistik.

Jakarta: Bumi Aksara.

Wijaya.2010. Statistika Nonparametrik.

Bandung: Alpabeta

84| J P D, p-I S S N : 2252 - 8156 , e - I S S N : 2579 - 3993 